\title{
Mindfulness in Ethical Consumption: The Mediating Roles of Connectedness to Nature and Self-control
}

\begin{tabular}{|r|l|}
\hline Journal: & International Marketing Review \\
\hline Manuscript ID & IMR-01-2019-0023.R3 \\
\hline Manuscript Type: & Original Article \\
\hline Keywords: & $\begin{array}{l}\text { Mindfulness, Ethical consumption, Consumption refinement, } \\
\text { Consumption reduction, mediating effects }\end{array}$ \\
\hline \multicolumn{2}{|l}{} \\
\hline
\end{tabular}

\section{SCHOLARONE \\ Manuscripts}




\title{
Mindfulness in Ethical Consumption: The Mediating Roles of Connectedness to Nature and Self-control
}

\begin{abstract}
Purpose: Ethical consumption is an integral component for the sustainable development in the world and is especially challenging in the Western consumer society. This research demonstrates that mindfulness, a Buddhism-based notion, is associated with two related and distinctive approaches of ethical consumption: refinement and reduction. It examines the psychological mechanisms underlying the effects of mindfulness on these two approaches of ethical consumption.
\end{abstract}

Design/methodology/approach: Self-report data were collected through an online survey with consumers from western societies $(N=523)$.

Findings: The findings show (1) that the significance of mindfulness on both approaches of ethical consumption and (2) that the contrast between the different mechanisms underlying them. Specifically, the mindfulness-consumption refinement link is fully mediated by connectedness-to-nature whereas the mindfulness-consumption reduction link is fully mediated by connectedness-to-nature and self-control. A series of supplementary studies further confirmed the proposed model.

Research limitations/implications: It demonstrates the multifaceted and complex nature of ethical consumption, which is positively associated with mindfulness but through distinctive psychological mechanisms.

Social implications : The findings can be adopted to enhance the effectiveness of mindfulness practice in promoting ethical consumption towards achieving the Sustainable Consumption goal, especially in the West.

Originality/value: The paper makes original contribution by conceptualizing two interrelated and distinctive approaches of ethical consumption and shows how mindfulness promotes both through different mediating pathways. Overall, this study paints a clearer picture how mindfulness relates to ethical consumption.

Keywords: Mindfulness; ethical consumption; consumption reduction; consumption refinement; mediating effects 


\title{
Mindfulness in Ethical Consumption: \\ The Mediating Roles of Connectedness to Nature and Self-control
}

\begin{abstract}
1. Introduction
It is inevitable that mindfulness and other practices adopted from Buddhism will find new applications in the modern West, where worldviews and lifestyles are so different from those of Southern and Eastern Asia. _ Bodhi (2011, p. 36).
\end{abstract}

Consumption and its impact on sustainable development has risen to a global top priority. In 2015, the United Nations set out the 2030 Agenda for Sustainable Development and Sustainable Development Goals, one of which specifically aims to "ensure sustainable consumption and production patterns", and reduce future economic, environmental, and social costs (United Nations, 2015). In 2017, worldwide material consumption reached 92.1 billion tons, up from 27 billion in 1970, with the rate of extraction accelerating every year since 2000 (United Nations, 2019a). A comparison between high-income and other countries based on the United Nations country classification paints an imbalanced picture: the material footprint per capita of highincome countries is more than 13 times that of low-income countries at 2 metric tons (United Nations, 2019b), the unsustainable consumption is more severe in the West.

To reduce the material footprint and achieve the goal of sustainable consumption, consumers can refine their consumption decisions, such as choosing Fairtrade-certified products or reduce their consumption through choosing a simple and frugal lifestyle. Tensions behind ethical consumption appear to be less salient among consumers in Eastern than Western societies (Pecoraro and Uusitalo, 2014). Such differences might be associated with the ancient wisdom and beliefs of Eastern philosophies that advocate a simple and non-luxury life, long-term 
planning, and anti-egoism (Ram-Prasad, 2005), which are more in line with the values and norms driving ethical consumption. An emerging but rapidly growing body of literature explores the relationship between ethical consumption and mindfulness, a notion and practice central to the Buddhist teachings which has been widely adapted and applied in psychotherapy and psychological science (e.g., Bahl et al., 2016; Ericson et al., 2014; Fischer et al., 2017). Taking a social psychology perspective of mindfulness, these recent works unanimously demonstrate the potential impact of mindfulness on ethical consumption (see a summary of the relevant literature in Appendix). In Western psychology, mindfulness refers to "the state of being attentive to and aware of what is taking place in the present", and emphasizes consciousness, awareness, and attention (Brown and Ryan, 2003, p. 822). This research argues that mindfulness provides a unifying framework for understanding consumption refinement and reduction, as both require awareness, consciousness, and attention to one's decisions and the consequences. Specifically, it examines whether and how mindfulness is associated with socially and environmentally responsible consumption as manifestations of consumption refinement, as well as with voluntary simplicity lifestyle practices and frugal purchasing as manifestations of consumption reduction.

Thus, this research contributes to the mindfulness-ethical consumption research by developing a conceptual framework that recognizes the complex and diverse forms of ethical consumption and identify mindfulness as a common and powerful approach promoting the various formats of ethical consumption. This research also responds to the calls by Mick (2017) for more consumer research insights built on Buddhist psychology, and by Bahl et al. (2016) for more research into the transformative potential of mindfulness in various consumption contexts. The results of an online survey with 523 respondents mainly from Western societies show 
significant and robust support of the positive association between mindfulness and the four different ethical consumption practices.

Second, this research uncovers the distinctive mediation mechanisms underlying the effects of mindfulness on consumption refinement and reduction, respectively. The burgeoning mindfulness research has not provided much answer as to the process of how mindfulness prompts ethical consumption behaviors, except for a few studies such as Barbaro and Pickett (2016) (Appendix). Our findings revealed two different mediating mechanisms: connectedness to nature but not self-control fully mediates the mindfulness-consumption refinement link, while both connectedness to nature and self-control mediate the mindfulness-consumption reduction link. These differential mediating mechanisms significantly advances the existing literature which examines the effects of mindfulness on only a single dimension of consumption ethics, such as pro-environmental choices (e.g., Geiger et al., 2018). Moreover, our findings on such underlying mechanisms provide specific methods through which marketers, social and environmental activists, and policymakers can harness the power of mindfulness to cultivate ethical consumerism.

\section{Literature Review and Hypothesis Development}

\subsection{Ethical Consumption: Refinement and Reduction}

The scope of consumer ethical concerns expands, shifts, and differs across disciplines, and the literature has generally acknowledged the complex and multidimensional nature of ethical consumption and hence the difficulty in defining it (Bray et al., 2011). In this study, ethical consumption is broadly defined as actions, decisions, and choices shaped by concerns for the well-being of others (e.g., Fairtrade coffee), the natural environment (e.g., less red meat) and oneself (e.g., overeating) in the consumption process. Consumers' ethical concerns may motivate 
them to adopt two interrelated but distinctive approaches to consumption: refinement and reduction. In consumption refinement, consumers refine their choices by choosing brands operated by well-performing businesses that exhibit corporate social responsibility, or by buying and using products that harm the environment less. In consumption reduction, consumers purposely reduce the current consumption levels through shifting to simple lifestyles or becoming more frugal in their consumption (Carrigan and Bosangit, 2016). Thus, both consuming better (refinement) and consuming less (reduction) are approaches to ethical consumption. This study suggests that the psychological mechanisms driving them share commonalities and yet differ at the same time.

Ethical consumption can be driven by political, religious, spiritual, environmental, social, or other motivations. For example, Bray et al. (2011) show that ethical obligation, inertia, cynicism, and situational factors (e.g., price of ethical products) influence ethical consumption decisions. In addition, ethical consumption behavior is influenced by normative social factors or extrinsic motivations such as social status and reputation (Elliott, 2013) as well as intrinsic factors such as empathy (Hwang and Kim, 2018) and a cosmopolitan mindset (Moosmayer et al., 2019). However, the impact of these factors would be less salient if consumers were to make their consumption choices in a mindless, routine, and automatic way. Therefore, mindfulness, which is associated with greater self-awareness and moment-to-moment attention, can provide a better explanation for ethical consumption (Ericson et al., 2014; Fischer et al., 2017).

\subsection{Mindfulness}

Mindfulness (Pāli sati, Sanskrit smrti) has a prominent position in Buddhist teaching (Gethin, 2015; Thich, 2019). The earliest textual records come from ancient Indian Buddhism, where mindfulness is situated as one of the central components of Buddhist praxis (Sun, 2014). 


\footnotetext{
${ }^{1}$ Although discrepancies persist between the usage of the Buddhist term "mindfulness" and its more traditional usage, research has shown that Buddhism and Western psychology have many common grounds. The Buddhist scholar Bodhi (2011) and the psychologist Baer (2011) both agree that inconsistencies in the meanings and usages of mindfulness, although inevitable, can be essential to the application of a valuable philosophical tradition in contemporary society in psychological research, practice, and therapy.
}

The introduction of mindfulness-based stress reduction (MBSR) (Kabat-Zinn, 1982) has secularized mindfulness as an intervention to improve cognitive and emotional well-being, which has further popularized mindfulness in Western societies. ${ }^{1}$ Despite being criticized for being oversimplified, secularized, and Westernized, mindfulness shares a clear common ground with its Buddhist original sati in that it emphasizes the presence of the mind and refers to a state of consciousness. As a mode of being, it is central to the human experience and is rooted in the fundamental activities of consciousness: attention and awareness (Brown and Ryan, 2003; Brown et al., 2007). Mindfulness is a natural human capacity that varies across individuals in terms of its frequency and intensity and can be improved through practice and training (Creswell, 2017). Mindfulness training helps develop specific beliefs and intentions toward the self and others, such as kindness, compassion, generosity, and equanimity, which are fundamental to human ethical values related to the animate and inanimate world (Grossman, 2015). Mindfulness also has positive effects on self-acceptance, self-esteem, and self-compassion, and leads to prosocial and altruistic behavior (Berry et al., 2018). These behavioral outcomes closely relate to the acts of ethical consumption (Appendix).

In a review, Fischer et al. (2017) note that mindfulness enhances the capacity of individuals to reflect upon their consumption habits, which in turn encourages sustainable consumption behavior through increasing the awareness of immediate daily experience, disrupting routines, cultivating non-material values and well-being, and developing compassion and prosocial behavior. This echoes Kabat-Zinn's view that mindfulness allows individuals to experience the 
present moment without the distortion of "routinized, habitual and unexamined activity of our thoughts and emotions often involving significant alienation from direct experience of the sensory world and the body" (Kabat-Zinn, 2003, p. 148). Hence, individuals with greater mindfulness are more aware of their present-moment thoughts, emotions, and responses, and are more able to break away from autopilot and mindless consumption practices (Bahl et al., 2016). As such, they are more conscious of acting on their beliefs and addressing their ethical concerns when making consumption decisions (Sheth et al., 2011).

Based on the above review, this study proposes a theoretical framework (Figure 1) to investigate how mindfulness is associated with the two approaches to ethical consumption: consumption refinement manifested by socially responsible and environmentally responsible consumption behaviors $(\mathrm{H} 1)$, and consumption reduction manifested by voluntary simplicity practices and frugal purchasing (H2). We also identify two different paths through which mindfulness affects these ethical consumption behaviors (H3 to $\mathrm{H} 6$ ).

INSERT FIGURE 1 ABOUT HERE

\subsection{Mindfulness and Consumption Refinement}

Two manifestations of consumption refinement address ethical concerns in social and environment aspects, respectively. First, consumers may buy options offered by businesses which prioritize social responsibilities (e.g., better hiring practices, active philanthropy) out of social concerns. Such consumption refinement exemplifies consumer social responsibility, a core component of consumer ethics in the same sense that corporate social responsibility (CSR) is a core component of business ethics (Schlaile et al., 2018). Second, consumers with environmental concerns may choose to buy environmentally friendly options while avoiding products that harm 
the natural environment. Shopping and consuming in a socially or an environmentally responsible manner demonstrate that consumers are constantly conscious of the well-being of others or the natural environment above and beyond their own desires.

Mindfulness affects socially and environmentally responsible consumption in two ways. First, it promotes socially responsible consumption by reducing self-focused concerns, enhancing self-world closeness, and correcting any distortion between perceived internal and external realities (Brown et al., 2016). Theorists informed by Buddhist and organismic psychologies suggest that heightened self-focused concerns are often due to a lack of awareness of one's thought patterns, emotional reactions, desires, and behavioral tendencies (Leary, 2007). Therefore, a clear and present-moment look at one's thoughts, emotions, and actions enabled by greater mindfulness should interrupt automatic self-representation and lead to greater self-world connections (Trautwein et al., 2014).

Second, mindfulness increases the concern about the resource footprint, thus promoting proenvironmental behavior. Many daily decisions and actions are a function of automatic processing (Bargh and Chartrand, 1999). Unless pro-environmental choices become the default, their enactment may depend on focused consideration of options. Mindfulness enhances people's focus on specific experiences, including feelings and thoughts about the natural world (Bishop et al., 2004). When people are mindful, they view subjective well-being and ecologically responsible behavior to be complementary rather than conflictual pursuits, because the quality of consciousness encourages reflection on the ecological impact of one's behavior (Brown and Kasser, 2005). Mindfulness creates a sensory connection with the world outside, increases the awareness of available sustainable options (Brown and Kasser, 2005), and thus promotes sustainable behavior. 
Mindful consumers are more likely to consider the public consequences of their private consumption (Webb et al., 2008). They are more willing to reward or punish companies based on their corporate social responsibility performance. They are also more inclined to prioritize social and environmental criteria over traditional criteria such as quality and price in purchases, and to avoid products that harm the environment. Therefore, we propose:

H1: Mindfulness is positively associated with consumption refinement that is (a) socially responsible and (b) environmentally responsible.

\subsection{Mindfulness and Consumption Reduction}

Merely substituting consumption options might not lead to a significant reduction in the overall consumption amounts and desires of consumers. The incremental impacts of using socially responsible, ecologically efficient, or "greener" product substitutions might be largely offset by substantial growth in global consumption (Peattie and Peattie, 2009). Reducing consumption could help directly reduce the material footprint by changing the ordinary consumption routines and downshifting consumption frequency, amounts, and activities. Two distinctive approaches_-voluntary simplicity lifestyle and frugal purchasing — can achieve such goals. Voluntary simplicity lifestyle refers to limiting material consumption to free one's money and time to seek for satisfaction of non-material aspects of life (Etzioni, 1998; Huneke, 2005). It emphasizes the values of material simplicity, ecological awareness, desire for smaller but closer community, self-determination, and personal growth, and its primary purpose is to pursue a sense of well-being, identity, and meaning to life via rejecting consumption-oriented lifestyles (Chowdhury, 2018). In contrast, frugal purchasing refers to moderation and restraint in consumption and resourcefulness in the use of goods and services in order to eliminate waste (Pepper et al., 2009). It is usually not voluntarily chosen by individuals and neither is it an 
ethically conscious choice but primarily driven by the personal pleasure of savings and waste reduction (Chowdhury, 2018).

Mindfulness may provide an antidote to consumerism as it promotes reflection on the ecological impact of one's consumption activities (Rosenberg, 2004). It disrupts and changes existing lifestyle routines via self-observation practices, which increase both the possibilities and choices of lifestyles beyond the mere materialistic pursuits advertised in consumerism (Brown and Kasser, 2005). Moreover, mindfulness cultivates openness, generosity, kindness, and mental clarity, facilitating one's investigation of the self and others, as well as personal experience. This exploration process helps to develop greater intrinsic and socially oriented values and behaviors, as opposed to materialistic and hedonistic values (Fischer et al., 2017). Therefore, mindfulness not only enhances one's well-being or promptencourages ecologically responsible behaviors (Brown and Kasser, 2005), but further encourages the adoption of values, norms, beliefs, and practices that favor a voluntary simplicity lifestyle, which contributes to consumption reduction.

Although environmental concerns might not be a key motivator for consumers to live frugally, frugality is regarded as an independent but significant predictor of spending little on oneself and engaging in positive environmental behaviors rather than environmental concerns (Kropfeld et al., 2018). Because frugal purchasing is driven by the pleasure associated with the resourceful use and saving of material goods and services, it is thus a lifestyle that relates to selfinterests instead of societal ones (Nepomuceno and Laroche, 2017). As mindfulness enhances the non-material values in people's lives (Ericson et al., 2014) and is also found to associate with a tendency toward less monetary-spending consumption activities (Brown and Kasser, 2005), this study posits that mindfulness is positively associated with frugal purchasing for two reasons. First, mindfulness may increase the likelihood for an individual to be aware of the pleasure of 
saving money and resources (Rick et al., 2008) that drives both a positive attitude toward frugality and frugal consumption practices. Second, mindfulness increases the consciousness of consumption and its consequences which enhance preference toward the efficient use of resources and avoidance of waste, which are also reasons which partly explain frugal purchasing. Therefore, we propose:

H2: Mindfulness is positively associated with consumption reduction that involves (a) voluntary simplicity lifestyle practices and (b) frugal purchasing.

\subsection{Mediation by Connectedness to Nature for Mindfulness on Consumption Refinement}

Connectedness to nature refers to the extent to which individuals include nature in their representation of themselves (Schultz, 2002), and indicates “individuals' experiential sense of oneness with the natural world" (Mayer and Frantz, 2004, p. 504). Buddhist principles have been linked to reconnecting self as part of nature (Fabjanski and Brymer, 2017), which might mediate the positive relationship between mindfulness and consumption refinement.

There is a significant and direct association between mindfulness and connectedness to nature (Barbaro and Pickett, 2016). The meta-analysis by Schutte and Malouff (2018) demonstrates that this relationship holds across different demographic populations (e.g., young and old, women and men). They argue that the key characteristics of mindfulness, such as open and non-judgmental awareness and moment-to-moment attention, facilitate the building of nature connectedness. Openness to experience and attentional capacity highly relate to nature connectedness (Nisbet et al., 2009). Moment-to-moment attention increases the richness and vitality of nature experiences (Brown and Ryan, 2003), allowing individuals to engage with nature more fully. 
Connectedness to nature can affect consumption refinement in two ways. First, connectedness to nature may elicit concerns for the wellness of others and of society, leading to socially responsible consumption behavior. Feelings of being a part of nature elicit positive relational emotions such as caring and loving (Vining et al., 2008), and positively predict prosocial behavior (Zhang et al., 2014). This is also associated with a greater tendency to take the perspective of another person (Mayer and Frantz, 2004), stimulating the desire to develop close relationships with other people and engagement in prosocial behavior that supports community wellness (Weinstein et al., 2009). Overall, these studies suggest that individuals who feel a greater connectedness to nature care about the welfare of other individuals and of society. Second, connection to nature fosters environmentally responsible consumption, because if the natural world is embedded in the self, any behavior that harms the natural world will be experienced as harming one's self (Mayer and Frantz, 2004). Such connectedness is associated with environmental values and beliefs (Hoot and Friedman, 2011), environmental concerns (Davis et al., 2009), and engagement in pro-environmental behaviors such as energy conservation and recycling (Barbaro and Pickett, 2016). In summary, we hypothesize the following mediating effects:

H3: Connectedness to nature mediates the relationship between mindfulness and consumption refinement that is (a) socially responsible and (b) environmentally responsible.

\subsection{Mediation by Connectedness to Nature for Mindfulness on Consumption Reduction}

Connectedness to nature also mediates the relationship between mindfulness and consumption reduction. As voluntary simplicity is essentially a practice of conscious living and the search of authentic self-identity (Huneke, 2005; Kropfeld et al., 2018) as opposed to specific 
actors in the marketplace, desires in voluntary simplicity lifestyles cannot be fulfilled through consumption. Instead, they rely on the exploration of the relationship between self and others, including nature and the environment. Voluntarily curtailing one's consumption levels and amounts also relates to altruistic motivations (Shaw and Newholm, 2002), as well as other selfinterested desires such as achieving more balance in life (Pepper et al., 2009). Mindfulness, which increases connectedness to nature, thus helps consumers develop their ideological identity with those that live "in a way that is outwardly simple and inwardly rich" (Elgin and Mitchell, 1977, p. 255).

Besides, through increasing one's connectedness to nature, mindfulness also increases the awareness of consumption efficiency, waste reduction, and saving. Frugal consumption is negatively associated with materialism but positively associated with self-transcendence values such as universalism and benevolence, both of which place greater emphasis on understanding, appreciation, tolerance, and protection for the welfare of all people and for nature (Pepper et al., 2009). Mindfulness promotes a non-material lifestyle, thus also positively influences frugal consumption tendency by increasing connectedness to nature. To summarize:

H4: Connectedness to nature mediates the relationship between mindfulness and consumption reduction that involves (a) voluntary simplicity lifestyle practices and (b) frugal purchasing.

\subsection{Mediation by Self-control for Mindfulness on Consumption Refinement}

Self-control refers to the ability to override or change one's inner responses, as well as to interrupt undesired behavioral tendencies and refrain from acting on them, which is widely regarded as a capacity to adapt the self so as to live happier and healthier lives (Tangney et al., 2004). Mindfulness can be viewed as a nonjudgmental and nonreactive awareness of experiences 
and the surrounding environment, and thus facilitates emotion and attention regulation and reduces the depletion of cognitive resources, which are crucial aspects of the self-control process (Friese et al., 2012). Mindfulness involves self-regulation, particularly of automatic or reactive autopilot tendencies of the mind (Bahl et al., 2016). Extensive clinical evidence shows that mindfulness intervention exercises (even for just a few minutes) can foster self-control (KabatZinn, 2003). Mindfulness facilitates self-control at both activation and exertion phases (Liang et al., 2018). For the activation of self-control, mindful individuals are more likely to detect their desires, impulses, and temptations in the present moment and thus avoid acting automatically. When exerting self-control, mindful awareness frees up cognitive resources that otherwise would be consumed by elaborating on the desire, and thus conserves the resources required to increase the capacity for self-control. Thus, we hypothesize a positive association between mindfulness and self-control capacity.

We further postulate that self-control promotes consumption refinement. Within consumption refinement, consumers choose options offered by businesses who prioritize social responsibilities or choose environmentally friendly options. While these choices enhance the well-being of others or the natural environment, they may involve some costs to the self in terms of money (e.g., if the environmentally responsible options are more expensive) or time (e.g., if those options are less convenient). Because pursuing personal gains could often be the natural and default response, to overcome their automatic selfish impulses, people need advanced psychological processes such as self-regulation (DeWall et al., 2008).

Several studies show the link between self-control and prosocial behaviors. Self-control mediates the links between parental attachment and prosocial behaviors across the sexes (Nie et al., 2016). Depletion of self-control reduces altruistic actions; for instance, individuals high on 
self-control depletion are less willing to help others (DeWall et al., 2008), but it may not reduce attitudes toward being prosocial (Osgood and Muraven, 2015). Factors such as moral identity can mitigate the negative effect of self-control depletion on prosocial behaviors (Joosten et al., 2015). To summarize:

H5: Self-control mediates the relationship between mindfulness and consumption refinement that is (a) socially responsible and (b) environmentally responsible.

\subsection{Mediation by Self-control for Mindfulness on Consumption Reduction}

Though driven by different motivations, both voluntary simplicity lifestyle and frugal purchasing require strong self-control ability in resisting the consumption temptation surrounding consumers' daily decision-making process (Ortega-Egea and García-de-Frutos, 2013). Self-control is regarded as an important determinant of one's ability to resist consumption (Baumeister, 2002; Nepomuceno and Laroche, 2017).

Both voluntary simplicity and frugality are important anti-consumption lifestyles leading to consumption reduction (Kropfeld et al., 2018). As both involve changing one's consumption routines and adapting to simple or frugal lifestyles, enhanced self-control can contribute to lifestyle changes. For example, individuals who choose voluntary simplicity usually try to cultivate self-reliance and increase their control over their daily lives, while minimizing dependence on marketplaces (Huneke, 2005). Moreover, self-regulating consumers can better resist the temptations of and overreliance on immediate materialistic gratification as the only way to obtain pleasure (Nepomuceno and Laroche, 2017). Self-control helps them derive a greater sense of achievement from avoiding excessive consumption, consistent with Rick et al. (2008) that frugality is driven by the pleasure of saving rather than the pain of spending. Overall, people with greater self-control capacity can seek happiness by setting up more clear standards 
2 Three additional studies were performed to verify the robustness of our proposed model, which includes analyses using alternative measures of mindfulness, voluntary simplicity, and consumption reduction as well as controlling the direct effects and mediating effects of various personality traits including empathy, self-reflexive consciousness, and cosmopolitan mindsets. Available upon request. (Baumeister et al., 1994). We thus hypothesize that self-control increases voluntary simplicity practices and frugal purchasing.

To summarize, mindfulness helps cultivate healthier and more ethical consumption habits via increasing one's self-control capacity to repair the fragile self, which are significant motives for both voluntary simplicity and frugal consumption lifestyles. With an increased self-control capability, mindful people can also shift resources to reclaim vital energy, maintain comfort, or promote their inner growth (Mick, 2017), and in turn increase the tendency to choose an alternative simple or frugal lifestyle. Thus,

H6: Self-control mediates the relationship between mindfulness and consumption reduction that involves (a) voluntary simplicity lifestyle practices, and (b) frugal purchasing.

\section{Method}

We first describe the data collection procedure and the measures, and then conducted multiple analyses to assess the relationships between mindfulness and ethical consumption. ${ }^{2}$

\subsection{Participants and Procedure}

We recruited 546 online participants through Prolific, an online research platform that resemble Amazon's Mechanical Turk in facilitating reliable and high-quality data collection (Palan and Schitter, 2018). Participants upon completing the survey could receive US\$3.8. We applied the demographic filter in Prolific and restricted the participants to those born in the 
United States or the United Kingdom. ${ }^{3}$ We eliminated 23 unreliable responses, as these were completed very quickly and the same answers to all the questions were chosen. Table 1 reports the sample demographics.

INSERT TABLE 1 ABOUT HERE

\subsection{Measures}

All measures are adopted or adapted from existing literature. Except for those noted below, most of the scales are measured on a five-point Likert scale, anchored "strongly disagree" (1) to “strongly agree" (5).

Consumption refinement. We adopted two dimensions of the Social Responsible Purchase and Disposal $(S R P D)$ scale (Webb et al., 2008) on a five-point rating scale $(1=$ never true, $5=$ always true), including (a) socially responsible consumption through purchasing from firms with excellent corporate socially responsible performance (CSRP) (13 items) and (b) environmentally responsible consumption by avoiding buying or reducing the use of products that have negative environmental impacts (ENVIRON) (7 items). The remaining dimension on recycling behavior is excluded because it is more about product disposal and is inconsistent with our conceptualization of consumption refinement. The exploratory factor analysis (EFA) identifies CSRP and ENVIRON as two different factors and the Cronbach's alpha ( $\alpha$ ) are .94, and .86, respectively. A composite score was calculated for each factor.

Consumption reduction. For voluntary simplicity, we adopted the 21 -item measure from Huneke (2005) by asking respondents to rate their own consistency in practicing different aspects of voluntary simplicity on a nine-point scale $(\alpha=.87)$. These diverse practices include

\footnotetext{
${ }^{3}$ The US and the UK are typically non-East Asian societies where Buddhist practices and thoughts are increasingly popular (Khazan, 2019).
} 
not only less consumption, but also community engagement, better time use, limit of TV/Ads, and development of spiritual life. Because a person defined as pursuing a voluntary simplicity lifestyle does not necessarily engage in all these practices simultaneously, we thus believe that each of these practices contributes to, instead of being driven by, voluntary simplicity. In other words, all the 21 practices are formative indicators of voluntary simplicity instead of reflective indicators of the latent variable of voluntary simplicity. Aligning with the literature that suggests that formative scales should be used on the condition that the indicators are "viewed as causing rather than being caused by the latent variable measured by the indicators" (MacCallum and Browne, 1993, p. 533), we treated the Huneke (2005) scale as formative, rather than reflective. For frugal purchasing, we adopted a 6-item measure from Pepper et al. (2009) $(\alpha=.81)$.

Mindfulness. We adopted the 15-item Mindful Attention Awareness Scale (MAAS), (Brown and Ryan, 2003), which conceptualizes mindfulness as a trait measured on a 6-point scale $(1=$ almost always, $6=$ almost never $)(\alpha=.90)$.

Mediators. (1) Connectedness to nature. We adapted the 14-item measure of Mayer and Frantz (2004) and dropped 3 items due to the low factor loading in our model $(\alpha=.92)$. (2) Selfcontrol. The 13-item scale of Tangney et al. (2004) was adopted to measure how the respondents typically fared in various aspects of exerting self-control on a 5-point scale $(1=$ not at all, $5=$ very much) $(\alpha=.86)$.

Control variables. We controlled five demographic characteristics: age, household size, education, employment status, and income. We also controlled personality factors that might affect consumers' ethical consumption behavior, such as the 5-item scale of intrinsic religiosity $(\alpha=.87)$, which is found to affect voluntary simplicity (Chowdhury, 2018), the 9-item scale of spirituality $(\alpha=.92)$, taken from the International Personality Item Pool (similar to the Values in 
Action Inventory; Peterson and Seligman, 2004), as well as locus of control measured on a 23item unidimensional scale (Rotter, 1966), with higher (lower) measures reflecting an internal (external) locus of control.

\subsection{Measurement Model}

First, we used AMOS 26.0 to conduct the CFA to estimate our measurement model including our key unidimensional variables that we adopted from the existing literature following the two-step approach in Anderson and Gerbing (1988). The initial measurement model analyses, which included all items of the scales ${ }^{4}$, suggested that the model needed improvements. Three out of the fourteen items of connectedness to nature demonstrated very low factor loading $(<$. 40) and the modification index reported in the initial AMOS results also showed high error correlations among these three items. With these three items dropped, the revised model yielded an acceptable fit $\left(\chi^{2}=4631.08, \mathrm{df}=1991, \mathrm{p}<.001\right.$, goodness of fit $(\mathrm{GFI})=.86$, comparative fit index $(\mathrm{CFI})=.86$, incremental fit index $(\mathrm{IFI})=.86$, and root mean square error of approximation $($ RMSEA $)=.05)$; all coefficients were significant. The Cronbach's alphas (ranging from .81 to .94) were acceptable for construct reliability. The CR exceeded .70 (ranging from .73 to .93). The average variance extracted (AVEs) were above the .50 threshold, except for Mindfulness and Self-control. According to Fornell and Larcker (1981), even if AVE is lower than .5, if CR is higher than .6, the convergent validity of the construct is still adequate. Given that the CR of Mindfulness (.81) and of Self-Control (.84) were far above the threshold, the convergent validity of our measures was established. For the discriminant validity, our findings also fulfilled the requirement that AVE should exceed the squared correlation (Table 2). Overall, our findings

\footnotetext{
${ }^{4}$ We only included the composite measure of voluntary simplicity by Huneke (2005) in our CFA model because it is treated as a formative scale in our model testing.
} 
supported both the convergent and discriminant validities of each scale (Fornell and Larcker, 1981). For each determined factor, we calculated a composite score by averaging all items under the corresponding construct. Table 2 summarizes the key statistics and correlations.

INSERT TABLE 2 ABOUT HERE

Common method bias can be a concern for the self-report data by a single group of respondents used in this research. We ran Harman's one-factor test to assess the potential bias (Podsakoff and Organ, 1986). An EFA with all our variables produced a multifactor solution, accounting for $63.58 \%$ of the total variance. The first factor explained $13.66 \%$ of the variance, and no single factor accounted for the majority of the variance. We also conducted CFA where all the measured items loaded on one latent factor. This single-factor measurement model showed very poor model fit, suggesting that one-factor solution did not fit our data. Overall, these two tests showed that common method bias was not a major concern in our data.

\subsection{Testing for the Relationships between Mindfulness and Ethical Consumption}

To test the relationships between mindfulness and ethical consumption, we employed a structural equation modeling approach using AMOS 26. Specifically, our model included the demographic and personality factors (i.e., intrinsic religiosity, spirituality, locus of control) as the control variables predicting ethical consumption.

We first tested the main effect and included only Mindfulness, control variables, and four dependent variables. The modification index in the original model suggested the correlations between the errors of CSRP, ENVIRON, and voluntary simplicity, which might be driven by the latent concept of ethical consumption. In addition, following the suggestions of modification index in our initial model estimation, we also allowed the control variables to be correlated. We added these three pairs of error correlations and correlations of the control variables to the 
model, which yielded an acceptable fit: $\chi^{2}=67.50$, df $=12, \mathrm{p}<.001, \mathrm{GFI}=.98, \mathrm{CFI}=.97$, IFI $=.97$, and RMSEA $=.094$. We found significant main effects of mindfulness on ENVIRON $(\beta$ $=.154, \mathrm{p}<.001)$, voluntary simplicity $(\beta=.257, \mathrm{p}<.001)$, and frugal purchasing $(\beta=.394, \mathrm{p}$ $<.001$ ), in support of $\mathrm{H} 1 \mathrm{~b}, \mathrm{H} 2 \mathrm{a}$, and $\mathrm{H} 2 \mathrm{~b}$. However, there is no significant main effect on CSRP. To test the mediation effects, we examine a fully mediated model (i.e., direct paths from mindfulness to the dependent variables were removed), which yielded the model fit: $\chi^{2}=132.68$, $\mathrm{df}=33, \mathrm{p}<.001, \mathrm{GFI}=.97, \mathrm{CFI}=.95, \mathrm{IFI}=.95, \mathrm{TLI}=.85$, and $\mathrm{RMSEA}=.076$. We had also run a partially mediated model but find it inferior to the fully mediated model. Our findings showed that mindfulness significantly affected both connectedness to nature $(\beta=.227, \mathrm{p}<.001)$ and self-control $(\beta=.565, \mathrm{p}<.001)$. Connectedness to nature significantly affected $C S R P(\beta$ $=.329, \mathrm{p}<.001), \operatorname{ENVIRON}(\beta=.473, \mathrm{p}<.001)$, voluntary simplicity $(\beta=.412, \mathrm{p}<.001)$, and frugal purchasing $(\beta=.124, \mathrm{p}<.01)$. In contrast, self-control only significantly affected voluntary simplicity $(\beta=.143, \mathrm{p}<.001)$ and frugal purchasing $(\beta=.315, \mathrm{p}<.001)$, showing no significant effect on either measure of consumption refinement. Overall, the SEM results provided preliminary support for $\mathrm{H} 3, \mathrm{H} 4$, and $\mathrm{H} 6$, but not for $\mathrm{H} 5 \mathrm{a}$ and $\mathrm{H} 5 \mathrm{~b}$.

\subsection{Bootstrapped Mediation Test}

To better capture and test the significance of each specific direct and indirect effect proposed in our model, we further followed the mediation effects testing procedures proposed by Zhao et al. (2010) and conducted the bias-corrected bootstrapped analysis $(\mathrm{n}=5,000)$ and 95\% confidence intervals in AMOS 26. Unlike the previous tests in which we included all four dependent variables in the same model, we tested the proposed mediating effect for each type of ethical consumption separately. As we have two different mediators in our model, we used the user-defined estimands approach in AMOS to construct and specify the estimate for each indirect 
path (e.g., indirect effect of mindfulness through connectedness to nature vs. indirect effect of mindfulness through self-control) on each dependent variable to estimate the significance of each mediating effect. Overall, the four models fit our data very well. The parsimonious fit was $\chi^{2} / \mathrm{df}$ $=4.461$, which is below the threshold value of 5 . Our absolute fit--and-_error measure was around the desired value of $.08($ RMSEA $=.081)$. Various model fit indexes all achieved satisfactory levels larger than $.90(\mathrm{CFI}$ ranging from .928 to .934 , AGFI $=.965)$. The bootstrapped mediation test results of each model are reported in Table 3 .

\section{INSERT TABLE 3 ABOUT HERE}

For consumption refinement, we found significant indirect effects of mindfulness through connectedness to nature on $\operatorname{CSRP}(\beta=.085, \mathrm{p}<.001)$ and on $\operatorname{ENVIRON}(\beta=.118, \mathrm{p}<.001)$. The indirect effect of mindfulness on consumption refinement through self-control is not statistically significant on either CSRP or ENVIRON, and consequently there is no mediation through self-control. Overall, our results support $\mathrm{H} 3 \mathrm{a}$ and $\mathrm{H} 3 \mathrm{~b}^{5}$, but not $\mathrm{H} 5 \mathrm{a}$ and $\mathrm{H} 5 \mathrm{~b}$. The results showed that mindfulness affected individuals' decisions to refine their consumption options and to be socially and environmentally responsible primarily through increasing their concerns beyond themselves (i.e., connectedness to nature) rather than suppressing their consumption preference (i.e., self-control). Furthermore, the results indicated that the direct effect of mindfulness on consumption refinement became insignificant $(\beta=-.006, p>.10 ; \beta$

\footnotetext{
${ }^{5}$ Although mindfulness has no significant total effect on CSRP, however, according Zhao??et al. (2010), the significance of the total effect of the independent variable is not a condition necessary to establish the mediation effect. Instead, they suggest that the mediation effect is significant as long as the indirect effect through the mediator is significant. In our case, the mediating effect is regarded as significant as the indirect effect of mindfulness on CSRP through connectedness to nature is significant.
} 
$=.022, \mathrm{p}>.10$ ) when considering the mediating effects via connectedness to nature, thus suggesting full mediation.

For consumption reduction, our results show significant indirect effects of mindfulness on voluntary simplicity via both connectedness to nature $(\beta=.140, \mathrm{p}<.01)$ and self-control $(\beta$ $=.149, \mathrm{p}<.01)$. Similarly, the indirect effects of mindfulness on frugal purchasing via connectedness to nature $(\beta=.030, \mathrm{p}<.05)$ and self-control $(\beta=.177, \mathrm{p}<.01)$ are both significant. These results support H4a, H4b, H6a, and H6b. Furthermore, the results indicate that the direct effect of mindfulness on voluntary simplicity and frugal purchasing became insignificant ( $\beta=-.067, p>.10$, and $\beta=.068, p>.10$ respectively) when controlling for the mediators, thus suggesting full mediation. Overall, our findings suggested that mindfulness affected consumption reduction and consumption refinement via different mechanisms as proposed.

\section{Discussions and Conclusions}

The present study incorporates mindfulness - a central component of Buddhism teaching into the examination of two interrelated yet distinctive approaches to ethical consumption: consumption refinement and consumption reduction. As practicing ethical consumption inherently requires attention and consciousness, mindfulness is found to be positively associated with both reduction and refinement. Hence, we contribute to the research on ethical consumption by identifying a common driver — mindfulness — and by contrasting the different psychological processes through which its effects take place. The findings thus significantly enrich our understanding of the multifaceted issues of ethical consumption.

This research captures the relationship between mindfulness and two representative practices in consumption refinement. We have found a significant direct association between mindfulness 
and environmentally responsible consumption, and an indirect association between mindfulness and socially responsible consumption via enhancing one's connectedness to nature. It provides additional support to previous findings on the positive effects of mindfulness on prosocial behavior (Condon et al., 2013), but extends to the context of ethical consumption.

Our research is the first to conceptually argue and empirically demonstrate that mindfulness facilitates consumption reduction manifested by voluntary simplicity lifestyles and frugal purchasing. Consumption reduction has received limited attention in the literature, but it critically affects the well-being of individuals, society, and the environment (Carrigan and Bosangit, 2016).

We have identified and compared how mindfulness affects the two forms of ethical consumption via different mediation processes. In the first path, mindfulness facilitates a psychological connection to nature, which in turn leads to engaging in socially and environmentally responsible consumption as well as adapting simpler and more frugal lifestyles. While the mediating role of connectedness to nature in ecological behavior has been demonstrated (Barbaro and Pickett, 2016), this present study shows that connectedness to nature also mediates the effect of mindfulness on another manifestations of consumption refinement (i.e., socially responsible consumption) as well as consumption reduction. It shows that mindfulness, through a greater sense of connection to nature, can promote ethical consumption in an overarching way.

In the second path, mindfulness helps exert self-control and in turn inhibits desire to consumer excessively, because reducing consumption requires substantial change of routines and lifestyles. We show that consumption reduction practices not only require the connectedness to nature, but also the awareness of one's actions, afforded by mindfulness. Although previous 
research has demonstrated the importance of self-control in reducing compulsive or impulsive buying (Faber and Vohs, 2004), this study is the first to empirically confirm the mediating effect of self-control on the mindfulness-consumption reduction relationship.

Lastly, we empirically demonstrated the distinctiveness of the two approaches to ethical consumption by incorporating the two potential mediators simultaneously in the analyses. Such analyses allowed us to show that different factors emerged as the dominant and significant mediator of the link between mindfulness and either approach of ethical consumption.

Our results provide important social implications. When people are more mindful, they can feel more connected to nature and can develop stronger self-control, which helps them to choose more ethical product options and to resist compulsive and conspicuous consumption.

Mindfulness is a trainable quality (Goleman and Davidson, 2017), in that it can be enhanced through meditation and mindfulness training. Our results imply that it may be useful to include mindfulness practices in ethical education interventions. If mindfulness training can provide a practical means to increase connectedness to nature and improve self-control, such training could be conducive to sustainable consumption, and contribute to shaping lifestyles and consumption cultures in order to be more responsible and ethical. Besides, training can focus on more specific issues, such as understanding one's own consumption patterns (e.g., buying secondhand), which can be incorporated gradually in everyday life (Kirby, 2019). Indeed, recent research shows that specific mindfulness training with situational cues can better bridge the intention-behavior gap for behavioral changes (Papies, 2017).

One limitation of the current study is that our measures of mindfulness reflect chronic dispositions (rather than states) and therefore the relationships with the ethical consumption practices that we reveal are correlational in nature (rather than causal). Future studies could 
include experiments that involve mindfulness interventions to draw causal conclusions.

Longitudinal studies could be further conducted to examine the effects of shorter- or longer-term mindfulness training. 


\section{References}

Anderson, J.C. and Gerbing, D.W. (1988), "Structural equation modeling in practice: A review and recommended two-step approach", Psychological Bulletin, Vol. 103 No. 3, pp. 411423.

Baer, R.A. (2011), “Measuring mindfulness”, Contemporary Buddhism, Vol. 12 No. 1, pp. 241261.

Bahl, S., Milne, G.R., Ross, S.M., Mick, D.G., Grier, S.A., Chugani, S.K., Chan, S., Gould, S.J., Cho, Y.-N., Dorsey, J.D., Schindler, R.M., Murdock, M.R. and Mariani, S.B. (2016), "Mindfulness: The transformative potential for consumer, societal, and environmental well-being", Journal of Public Policy \& Marketing, Vol. 35 No. 2, pp. 1-13.

Barbaro, N. and Pickett, S.M. (2016), "Mindfully green: Examining the effect of connectedness to nature on the relationship between mindfulness and engagement in pro-environmental behaviour", Personality and Individual Differences, Vol. 93, pp. 137-142.

Bargh, J.A. and Chartrand, T.L. (1999), "The unbearable automaticity of being", American Psychologist, Vol. 54 No. 7, pp. 462-479.

Baumeister, R.F. (2002), "Yielding to temptation: Self-control failure, impulsive purchasing, and consumer behaviour", Journal of Consumer Research, Vol. 28 No. 4, pp. 670-676.

Baumeister, R.F., Heatherton, T.F. and Tice, D.M. (1994), Losing Control: How and Why People Fail at Self-regulation, Academic Press, San Diego, CA.

Berry, D.R., Cairo, A.H., Goodman, R.J., Quaglia, J. T., Green, J.D. and Brown, K.W. (2018), "Mindfulness increases prosocial responses toward ostracized strangers through empathic concern”, Journal of Experimental Psychology: General, Vol. 147 No. 1, pp. 93-112.

Bishop, S.R., Lau, M., Shapiro, S., Carlson, L., Anderson, N.D., Carmody, J., Segal, Z.V., Abbey, S., Speca, M., Velting, D. and Devins, G. (2004), "Mindfulness: A proposed operational definition”, Clinical Psychology: Science and Practice, Vol. 11 No. 3, pp. 230-241.

Bodhi, B. (2011), "What does mindfulness really mean? A canonical perspective", Contemporary Buddhism, Vol. 12 No. 1, pp. 19-39.

Bray, J., Johns, N. and Kilburn, D. (2011), "An exploratory study into the factors impeding ethical consumption", Journal of Business Ethics, Vol. 98, pp. 597-608.

Brown, K.W., Berry, D.R. and Quaglia, J.T. (2016), "The hypo-egoic expression of mindfulness", in Brown, K.W. and Leary, M.R. (Eds.), The Oxford Handbook of Hypoegoic Phenomena, Oxford University Press, New York, NY, pp. 147-159.

Brown, K.W. and Kasser, T. (2005), "Are psychological and ecological well-being compatible? The role of values, mindfulness, and lifestyle", Social Indicators Research, Vol. 74 No. 2, pp. 349-368.

Brown, K.W. and Ryan, R.M. (2003), "The benefits of being present: Mindfulness and its role in psychological well-being”, Journal of Personality and Social Psychology, Vol. 84 No. 4, pp. 822-848.

Carrigan, M. and Bosangit, C. (2016), "The challenges of responsible marketing and consumption", in Shaw, D., Chatzidakis, A. and Carrington, M. (Eds.), Ethics and Morality in Consumption: Interdisciplinary Perspectives, Routledge, New York, pp. 75-96.

Chowdhury, R.M.M.I. (2018), "Religiosity and voluntary simplicity: The mediating role of spiritual well-being", Journal of Business Ethics, Vol. 152, pp. 149-174.

Condon, P., Desbordes, G., Miller, W.B. and DeSteno, D. (2013), "Meditation increases compassionate responses to suffering”, Psychological Science, Vol. 24, pp. 2125-2127. 
Creswell, J.D. (2017), "Mindfulness interventions", Annual Review of Psychology, Vol. 68, pp. 491-516.

Davis, J.L., Green, J.D. and Reed, A. (2009), "Interdependence with the environment: commitment, interconnectedness, and environmental behaviour", Journal of Environmental Psychology, Vol. 29, pp. 173-180.

DeWall, C.N., Baumeister, R.F., Gailliot, M.T. and Maner, J.K. (2008), "Depletion Makes the Heart Grow Less Helpful: Helping as a Function of Self-regulatory Energy and Genetic Relatedness", Personality and Social Psychology Bulletin, Vol. 34 No. 12, pp. 1653-1662.

Elgin, D. S., and Mitchell, A. (1977), "Voluntary simplicity: Life-style of the future?", The Futurist, Vol. 11, pp. 200-206

Elliott, R. (2013), "The taste for green: the possibilities and dynamic of status differentiation through 'green' consumption", Poetics, Vol. 41 No. 3, pp. 294-322.

Ericson, T., Kjonstad, B.G. and Barstad, A. (2014), "Mindfulness and sustainability," Ecological Economics, Vol. 104, pp. 73-79.

Etzioni, A. (1998), "Voluntary simplicity: Characterization, select psychological implications, and societal consequences", Journal of Economic Psychology, Vol. 19 No. 5, pp. 619-643.

Faber, R.J. and Vohs, K.D. (2004), "To buy or not to buy?: Self-control and self-regulatory failure in purchase behaviour", in Baumeister, R.F. and Vohs, K.D. (Eds.), Handbook of Self-regulation: Research, Theory, and Applications, Guilford Press, New York, NY, pp. $509-524$.

Fabjanski, M. and Brymer, E. (2017), "Enhancing health and wellbeing through immersion in nature: A conceptual perspective combining the stoic and Buddhist traditions", Frontiers in Psychology, Vol. 8, DOI: 10.3389/fpsyg.2017.01573.

Fischer, D., Stanszus, L., Geiger, S., Grossman, P. and Schrader, U. (2017), "Mindfulness and sustainable consumption: A systematic literature review of research approaches and findings", Journal of Cleaner Production, Vol. 162, pp. 544-558.

Fornell, C. and Larcker, D.F. (1981), "Evaluating structural equation models with unobservable variables and measurement error", Journal of Marketing Research, Vol. 18 No. 1, pp. 3950 .

Friese, M., Messner, C. and Schaffner, Y. (2012), "Mindfulness meditation counteracts selfcontrol depletion", Consciousness and Cognition, Vol. 21, pp. 1016-1022.

Geiger, S.M., Otto, S. and Schrader, U. (2018), "Mindfully green and healthy: An indirect path from mindfulness to ecological behaviour", Frontiers in Psychology, Vol. 8, DOI: 10.3389/fpsyg.2017.02306.

Gethin, R. (2015), "Buddhist conceptualizations of mindfulness", in Brown, K.W., Creswell, J.D. and Ryan, R.M. (Eds.), Handbook of Mindfulness: Theory, Research, and Practice, Guilford Publications, New York, NY, Chapter 2, (pp. 9-41).

Goleman, D. and Davidson, R.J. (2017), Altered Traits: Science Reveals How Meditation Changes Your Mind, Brain, and Body, Avery Publishing Group, New York, NY.

Grossman, P. (2015), "Mindfulness: Awareness informed by an embodied ethic", Mindfulness, Vol. 6, pp. 17-22.

Hoot, R.E. and Friedman, H. (2011), "Connectedness and environmental behavior: Sense of interconnectedness and pro-environmental behaviour", International Journal of Transpersonal Studies, Vol. 30, pp. 89-100. 
Huneke, M.E. (2005), "The face of the un-consumer: Ann empirical examination of the practice of voluntary simplicity in the United States", Psychology \& Marketing, Vol. 22 No. 7, pp. $527-550$.

Hwang, K. and Kim, H. (2018), “Are ethical consumers happy? Effects of ethical consumers' motivations based on empathy versus self-orientation on their happiness", Journal of Business Ethics, Vol. 151 No. 2, pp. 579-598.

Iyer, R. and Muncy, J.A. (2009), "Purpose and object of anti-consumption", Journal of Business Research, Vol. 62 No. 2, pp. 160-168.

Joosten, A., van Dijke, M., Van Hiel, A. and De Cremer, D. (2015), “Out of control? How loss of self-control influences prosocial behavior: The role of power and moral values", PLoS One, Vol. 10 No. 5.

Kabat-Zinn, J. (1982), “An outpatient program in behavioral medicine for chronic pain patients based on the practice of mindfulness meditation: Theoretical considerations and preliminary results", General Hospital Psychiatry, Vol. 4 No. 1, pp. 33-47.

Kabat-Zinn, J. (2003), "Mindfulness-based interventions in context: Past, present, and future", Clinical Psychology: Science and Practice, Vol. 10 No. 2, pp. 144-156.

Kirby, J. (2019), "Ethical consumerism and self-growth," https://ethical.net/ethical/ethicalconsumerism-and-self-growth/ (Accessed on July 5, 2020)

Khazan, O. (2019), "Why so many Americans are turning to Buddhism: The ancient Eastern religion is helping Westerners with very modern mental-health problems", The Atlantic, March 7, available at https://www.theatlantic.com/health/archive/2019/03/buddhismmeditation-anxiety-therapy/584308/ (accessed February 212020$).$

Kropfeld, M.I., Nepomuceno, M.V. and Dantas, D. C. (2018), "The ecological impact of anticonsumption lifestyles and environmental concern”, Journal of Public Policy \& Marketing, Vol. 37 No. 2, pp. 245-259.

Leary, M.R. (2007), The Curse of the Self: Self-awareness, Egotism, and the Quality of Human Life, Oxford University Press, New York, NY.

Liang, L.H., Brown, D.J., Ferris, D.L., Hanig, S., Lian, H. and Keeping, L.M. (2018), "The dimensions and mechanisms of mindfulness in regulating aggressive behaviors", Journal of Applied Psychology, Vol. 103 No. 3, pp. 281-299.

MacCallum, R.C. and Browne, M.W. (1993), "The use of causal indicators in covariance structure models: Some practical issues", Psychological Bulletin, Vol. 114, pp. 533-541.

Mayer, F.S. and Frantz, C.M. (2004), "The connectedness to nature scale: A measure of individuals' feeling in community with nature", Journal of Environmental Psychology, Vol. 24 No. 4, pp. 503-515.

Mick, D.G. (2017), "Buddhist psychology: Selected insights, benefits, and research agenda for consumer psychology", Journal of Consumer Psychology, Vol. 27 No. 1, pp. 117-132.

Moosmayer, D.C., Chen, Y. and Davis, S.M. (2019), "Deeds not words: A cosmopolitan perspective on the influences of corporate sustainability and NGO engagement on the adoption of sustainable products in China”, Journal of Business Ethics, Vol. 158, pp. 135154.

Nepomuceno, M.V. and Laroche, M. (2017), "When materialists intend to resist consumption: The moderating role of self-control and long-term orientation", Journal of Business Ethics, Vol. 143 No. 3, pp. 467-483. 
Nie, Y.G., Li, J.B. and Vazsonyi, A.T. (2016), "Self-control mediates the associations between parental attachment and prosocial behavior among Chinese adolescents", Personality and individual differences, Vol. 96, pp. 36-39.

Nisbet, E.K., Zelenski, J.M. and Murphy, S.A. (2009), “The nature relatedness scale: Linking individuals' connection with nature to environmental concern and behavior", Environment and Behavior, Vol. 41 No. 5, pp. 715-740.

Ortega-Egea, J.M. and García-de-Frutos, N. (2013), "Toward consumption reduction: An environmentally motivated perspective", Psychology \& Marketing, Vol. 30 No. 8, pp. 660675.

Osgood, J.M. and Muraven, M. (2015), "Self-control depletion does not diminish attitudes about being prosocial but does diminish prosocial behaviors", Basic and Applied Social Psychology, Vol. 37 No. 1, pp. 68-80.

Palan, S. and Schitter, C. (2018), "Prolific.ac-A subject pool for online experiment", Journal of Behavioral and Experimental Finance, Vol. 17, pp. 22-27.

Papies, E. K. (2017), "Situating inteventions to bridge the intention-behavior gap: A framework for recuting nonconcious processes for behavior change," Social and Personality Psychology Compass, Vol. 11 No. 7, 1-19.

Peattie, K. and Peattie, S. (2009), "Social marketing: A pathway to consumption reduction?", Journal of Business Research, Vol. 62, pp. 260-268.

Pecoraro, M.G. and Uusitalo, O. (2014), "Conflicting values of ethical consumption in diverse worlds-A cultural approach", Journal of Consumer Culture, Vol. 14 No. 1, pp. 45-65.

Pepper, M., Jackson, T. and Uzzell, D. (2009), "An examination of the values that motivate socially conscious and frugal consumer behaviours", International Journal of Consumer Studies, Vol. 33 No. 2, pp. 126-136.

Peterson, C. and Seligman, M.E.P. (2004), Character Strengths and Virtues: A Handbook and Classification, Oxford University Press, USA.

Podsakoff, P.M. and Organ, D.W. (1986), "Self-reports in organizational research: Problems and prospects", Journal of Management, Vol. 12 No. 4, pp. 531-544.

Ram-Prasad, C. (2005), Eastern philosophy, Weidenfeld and Nicolson, London, UK.

Rick, S.I., Cryder, C.E. and Loewenstein, G. (2008), "Tightwads and spendthrifts", Journal of Consumer Research, Vol. 34 No. 6, pp. 767-782.

Rosenberg, E.L. (2004), "Mindfulness and consumerism”, in Kasser, T. and Kanner, A.D. (Eds.), Psychology and consumer culture: The struggle for a good life in a materialistic world, American Psychological Association, Washington DC, pp. 107-125.

Rotter, J.B. (1966), "Generalized expectancies for internal versus external control of reinforcement," Psychological Monographs: General and Applied, Vol. 80 No. 1, pp. 128.

Schlaile, M.P., Klein, K. and Böck, W. (2018), "From bounded morality to consumer social responsibility: A transdisciplinary approach to socially responsible consumption and its obstacles", Journal of Business Ethics, Vol. 149 No. 3, pp. 561-588.

Schultz, P.W. (2002), "Inclusion with nature: The psychology of human-nature relations", in Schmuck, P. and Schultz, W. (Eds.), Psychology of Sustainable Development, Springer, Boston, MA, pp. 61-78.

Schutte, N.S. and Malouff, J.M. (2018), "Mindfulness and connectedness to nature: A metaanalytic investigation", Personality and Individual Differences, Vol. 127, pp. 10-14. 
Shaw, D. and Newholm, T. (2002), "Voluntary simplicity and the ethics of consumption", Psychology \& Marketing, Vol. 19 No. 2, pp. 167-185.

Sheth, J.N., Sethia, N.K. and Srinivas, S. (2011), "Mindful consumption: A customer-centric approach to sustainability", Journal of the Academy of Marketing Science, Vol. 39 No. 1, pp. 21-39.

Sun, J. (2014), "Mindfulness in context: A historical discourse analysis", Contemporary Buddhism, Vol. 15 No. 2, pp. 394-415.

Tangney, J.P., Baumeister, R.F. and Boone, A.L. (2004), "High self-control predicts good adjustment, less pathology, better grades, and interpersonal success", Journal of Personality, Vol. 72 No. 2, pp. 271-322.

Thich, P.H. (2019), "A Buddhist approach to consumption”, Journal of Marketing Management, Vol. 35 No. 5/6, pp. 427-450.

Trautwein, F.M., Naranjo, J.R. and Schmidt, S. (2014), "Meditation effects in the social domain: self-other connectedness as a general mechanism?" In Schmidt, S. and Walach, H. (Eds.) Meditation-neuroscientific Approaches and Philosophical Implications. Springer, Cham, pp. 175-198.

United Nations (2015), https://www.un.org/sustainabledevelopment/sustainable-consumptionproduction/. (accessed 25 August 2019).

United Nations (2019a), "Progress of goal 12 in 2019", https://sustainabledevelopment.un.org/sdg12. (accessed 25 August 2019).

United Nations (2019b), https://www.un.org/sustainabledevelopment/wpcontent/uploads/2019/07/Infographic-Responsible-Consumption-and-Production.pdf. (accessed 25 August 2019).

Vining, J., Merrick, M.S. and Price, E.A. (2008), "The distinction between humans and nature: Human perceptions of connectedness to nature and elements of the natural and unnatural", Research in Human Ecology, Vol. 15, pp. 1-11.

Webb, D.J., Mohr, L.A. and Harris, K.E. (2008), “A re-examination of socially responsible consumption and its measurement", Journal of Business Research, Vol. 61 No. 2, pp. 9198.

Weinstein, N., Przybylski, A.K. and Ryan, R.M. (2009), “Can nature make us more caring? Effects of immersion in nature on intrinsic aspirations and generosity", Personality and Social Psychology Bulletin, Vol. 35 No. 10, pp. 1315-1329.

Zhang, J.W., Piff, P.K., Iyer, R., Koleva, S. and Keltner, D. (2014), “An occasion for unselfing: Beautiful nature leads to prosociality", Journal of Environmental Psychology, Vol. 37, pp. $61-72$.

Zhao, X., Lynch Jr., J.G. and Chen, Q. (2010), "Reconsidering Baron and Kenny: Myths and truths about mediation analysis", Journal of Consumer Research, Vol. 37 No. 2, pp. 197206. 
Figure 1. Theoretical Framework: Effects of Mindfulness on Ethical Consumption

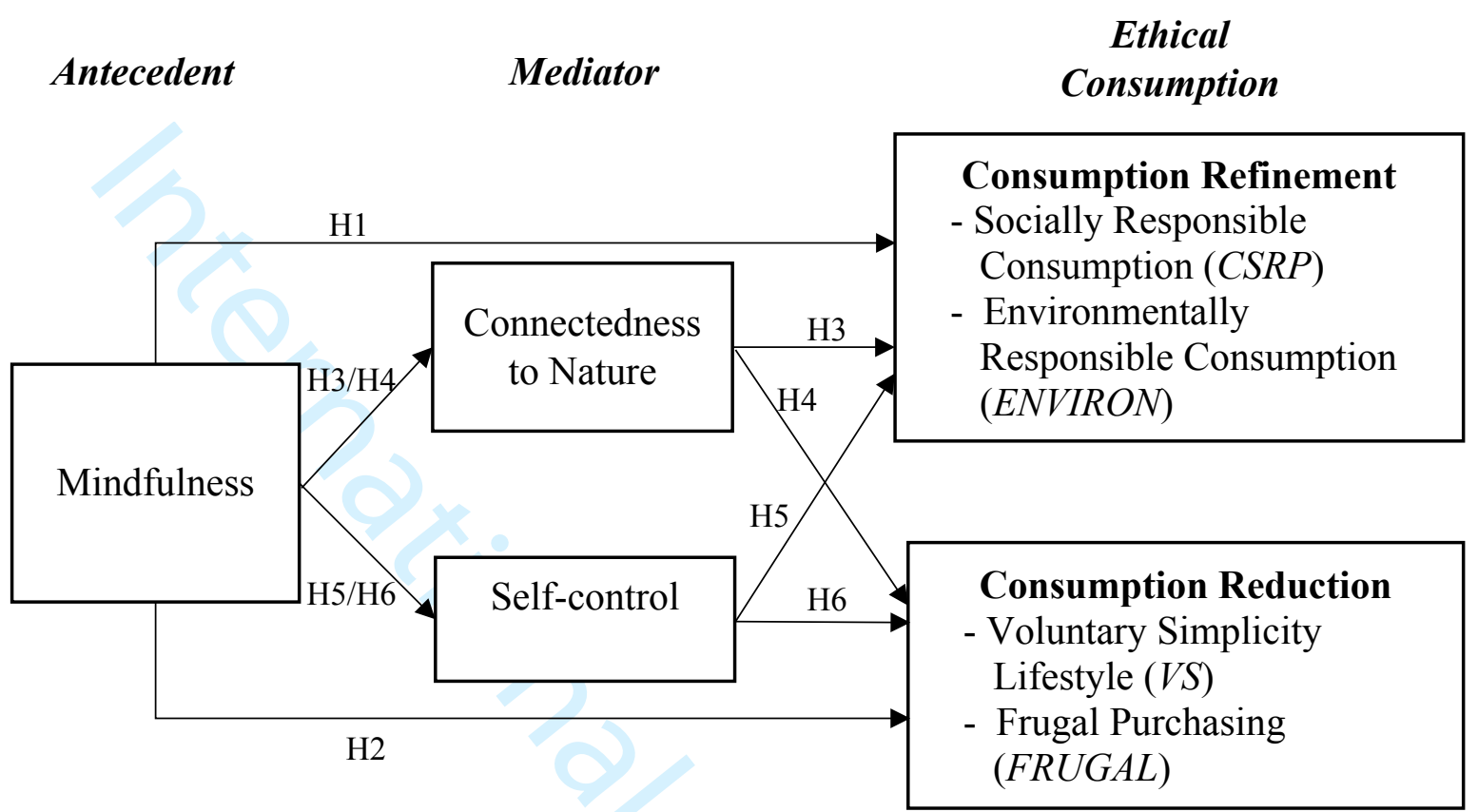

Notes: Control variables are included as drivers of all the dependent variables, but are not shown up in this figure. 
Table 1. Descriptive statistics

\begin{tabular}{|c|c|c|c|c|c|c|c|}
\hline Demographics & Frequency & Percent & $\begin{array}{c}\text { Cumulative } \\
\text { Percent }\end{array}$ & Demographics & Frequency & Percent & $\begin{array}{c}\text { Cumulative } \\
\text { Percent }\end{array}$ \\
\hline Gender & & & & Age & & & \\
\hline Female & 143 & 27.34 & 27.34 & Under 18 & 1 & 0.19 & 0.19 \\
\hline \multirow[t]{2}{*}{ Male } & 380 & 72.66 & 100.00 & $18-24$ & 82 & 15.68 & 15.87 \\
\hline & & & & $25-34$ & 192 & 36.71 & 52.58 \\
\hline Household Size & & & & $35-44$ & 109 & 20.84 & 73.42 \\
\hline Only me & 67 & 12.81 & 12.81 & $45-54$ & 76 & 14.53 & 87.95 \\
\hline Two people & 158 & 30.21 & 43.02 & $55-64$ & 50 & 9.56 & 97.51 \\
\hline Three people & 114 & 21.80 & 64.82 & $65-74$ & 13 & 2.49 & 100.00 \\
\hline Four people & 120 & 22.94 & 87.76 & & & & \\
\hline \multirow[t]{2}{*}{ Five or more people } & 64 & 12.24 & 100.00 & Income & & & \\
\hline & & & & Less than $\$ 12,700$ & 46 & 8.80 & 8.80 \\
\hline Education & & & & $\$ 12,700-\$ 25,399$ & 92 & 17.59 & 26.39 \\
\hline Below high school & 8 & 1.53 & 1.53 & $\$ 25,400-\$ 38,099$ & 104 & 19.89 & 46.27 \\
\hline High schoolor some college & 227 & 43.40 & 44.93 & $\$ 38,100-\$ 50,799$ & 103 & 19.69 & 65.97 \\
\hline College graduate & 205 & 39.20 & 84.13 & $\$ 50,800-\$ 63,499$ & 61 & 11.66 & 77.63 \\
\hline \multirow[t]{2}{*}{ Postgraduate degree } & 83 & 15.87 & 100.00 & $\$ 63,500-\$ 76,199$ & 41 & 7.84 & 85.47 \\
\hline & & & & $\$ 76,200-\$ 88,899$ & 28 & 5.35 & 90.82 \\
\hline Employment & & & & $\$ 88,900-\$ 101,599$ & 16 & 3.06 & 93.88 \\
\hline Employed full-time & 203 & 38.81 & 38.81 & $\$ 101,600-\$ 114,299$ & 10 & 1.91 & 95.79 \\
\hline Employed part-time & 115 & 21.99 & 60.80 & $\$ 114,300-\$ 126,999$ & 9 & 1.72 & 97.51 \\
\hline Self-employed/freelance & 68 & 13.00 & 73.80 & $\$ 127,000-\$ 190,500$ & 7 & 1.34 & 98.85 \\
\hline Unemployed & 137 & 26.20 & 100.00 & More than $\$ 190,500$ & 6 & 1.15 & 100.00 \\
\hline
\end{tabular}

Note: This is based on 523 observations. 
Table 2. Descriptive statistics and correlation analysis

\begin{tabular}{|c|c|c|c|c|c|c|c|c|c|c|c|c|c|c|c|c|}
\hline & & V1 & V2 & V3 & V4 & V5 & V6 & V7 & V8 & V9 & V10 & V11 & V12 & V13 & V14 & V15 \\
\hline V1 & CSRP & 0.593 & & & & & & & & & & & & & & \\
\hline v2 & Environmentally Responsible Consumption & $0.630^{* * *}$ & 0.505 & & & & & & & & & & & & & \\
\hline V3 & Voluntary Simplicity & $0.519^{* * *}$ & $0.650^{* * *}$ & NA & & & & & & & & & & & & \\
\hline V4 & Frugal Purchasing & 0.066 & $0.213^{* * *}$ & $0.229^{* * *}$ & 0.479 & & & & & & & & & & & \\
\hline V5 & Mindfulness & 0.025 & $0.124^{* * *}$ & $0.125^{* * *}$ & $0.255^{* * *}$ & 0.355 & & & & & & & & & & \\
\hline V6 & Connectedness to Nature & $0.331^{* * *}$ & $0.497^{* * *}$ & $0.446^{* * *}$ & $0.207^{* * *}$ & $0.226^{* * *}$ & 0.517 & & & & & & & & & \\
\hline V7 & Self-control & 0.045 & $0.155^{* * *}$ & $0.274^{* * *}$ & $0.335^{* * *}$ & $0.565^{* * *}$ & $0.237^{* * *}$ & 0.329 & & & & & & & & \\
\hline V8 & Age & $-0.076^{*}$ & 0.026 & 0.077 & $0.114^{* * *}$ & $0.200^{* * *}$ & $0.093^{* *}$ & $0.141^{* * *}$ & NA & & & & & & & \\
\hline V9 & Household Size & 0.033 & 0.031 & 0.001 & $-0.096^{* *}$ & $0.140^{* * *}$ & -0.010 & -0.022 & $-0.271^{* * *}$ & NA & & & & & & \\
\hline V10 & Education & 0.055 & $0.131^{* * *}$ & $0.183^{* * *}$ & 0.061 & 0.007 & $0.094^{* *}$ & $0.113^{* * *}$ & 0.014 & $-0.111^{* *}$ & NA & & & & & \\
\hline V11 & Employment & -0.030 & 0.052 & 0.006 & $0.126^{* * *}$ & 0.067 & 0.048 & 0.062 & $0.159^{* * *}$ & $0.083^{*}$ & $-0.189^{* * *}$ & NA & & & & \\
\hline V12 & Income & -0.042 & -0.061 & -0.033 & -0.059 & 0.035 & -0.009 & $0.087^{* *}$ & 0.006 & $0.183^{* * *}$ & $0.205^{* * *}$ & $-0.275^{* * *}$ & NA & & & \\
\hline V13 & Intrinsic Religiosity & $0.200^{* * *}$ & $0.134^{* * *}$ & $0.315^{* * *}$ & 0.049 & 0.047 & $0.122^{* * *}$ & $0.176^{* * *}$ & $0.083^{*}$ & 0.023 & $0.079^{*}$ & 0.050 & -0.038 & 0.702 & & \\
\hline V14 & Spirituality & $0.193^{* * *}$ & $0.114^{* * *}$ & $0.265^{* * *}$ & 0.048 & $0.105^{* *}$ & $0.179^{* * *}$ & $0.220^{* * *}$ & $0.123^{* * *}$ & 0.007 & 0.029 & 0.055 & -0.031 & $0.833^{* * *}$ & 0.581 & \\
\hline $\mathrm{V} 15$ & Locus of Control & -0.033 & 0.016 & $-0.073^{*}$ & 0.061 & $-0.092^{* *}$ & $-0.103^{* *}$ & $-0.123^{* * *}$ & 0.024 & -0.011 & -0.071 & 0.001 & -0.033 & -0.067 & $-0.154^{* * *}$ & NA \\
\hline & Mean & 2.695 & 3.257 & 4.491 & 4.896 & 3.841 & 3.401 & 2.980 & 3.725 & 2.916 & 2.694 & 2.266 & 4.126 & 1.904 & 2.230 & 33.501 \\
\hline & St. Dev. & 0.938 & 0.907 & 1.253 & 0.926 & 0.824 & 0.675 & 0.677 & 1.300 & 1.237 & 0.749 & 1.224 & 2.362 & 1.051 & 1.079 & 2.056 \\
\hline & Min. & 1.000 & 1.000 & 1.000 & 1.833 & 1.533 & 1.143 & 1.154 & 1.000 & 1.000 & 1.000 & 1.000 & 1.000 & 1.000 & 1.000 & 27.000 \\
\hline & Max. & 5.000 & 5.000 & 8.429 & 7.000 & 5.933 & 4.929 & 4.846 & 7.000 & 5.000 & 4.000 & 4.000 & 12.000 & 5.000 & 5.000 & 41.000 \\
\hline
\end{tabular}

Note: This is based on 523 observations. $* * *=<0.01, * *=<0.05, *=<0.1$. AVE of each key construct in our model is reported in the diagonal of the table. AVEs for voluntary simplicity and locus of control were not computed as they were treated as formative scales in our model. 
Table 3. Mindfulness: bootstrapped mediation test

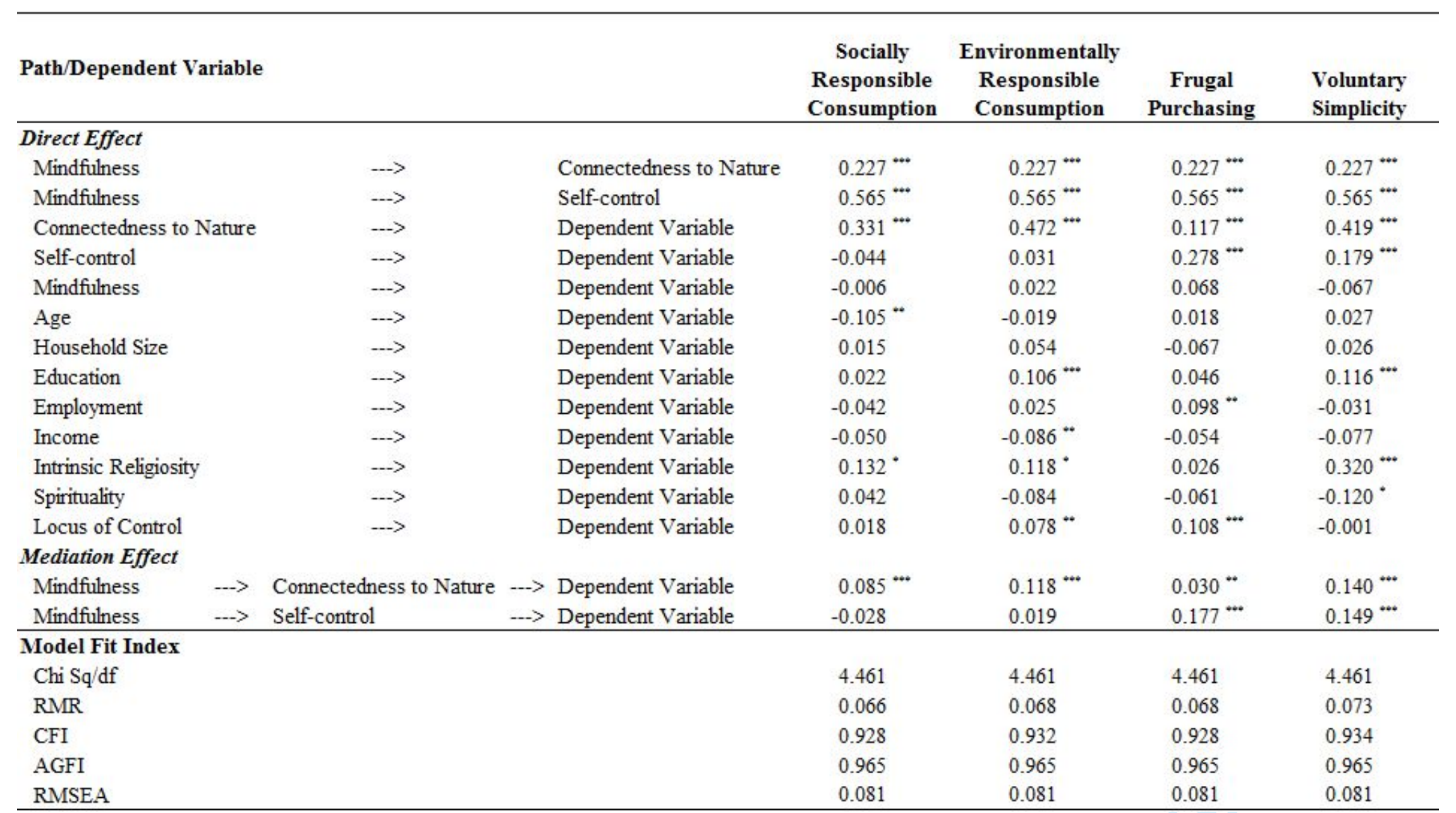

Note: This is based on 523 observations. $* * *=<0.01, * *=<0.05, *=<0.1$. 
Appendix: Select recent studies investigating mindfulness and ethical consumption

\begin{tabular}{|c|c|c|c|c|}
\hline Study* & $\begin{array}{l}\text { Research } \\
\text { approach }\end{array}$ & Mindfulness & $\begin{array}{l}\text { Ethical consumption } \\
\text { behavior outcomes }\end{array}$ & $\begin{array}{c}\text { Mediating } \\
\text { mechanisms and } \\
\text { effects }\end{array}$ \\
\hline \multicolumn{5}{|l|}{ Literature reviews } \\
\hline $\begin{array}{l}\text { Ericson et al., 2014, } \\
\text { Ecological Economics }\end{array}$ & $\begin{array}{l}\text { Literature } \\
\text { review and } \\
\text { conceptual } \\
\text { framework }\end{array}$ & $\begin{array}{l}\text { Awareness, } \\
\text { Mindfulness } \\
\text { mediation }\end{array}$ & $\begin{array}{l}\text { Sustainable behavior, } \\
\text { Pro-environmental intention }\end{array}$ & $\begin{array}{l}\text { (1) Well-being, (2) } \\
\text { values, empathy, } \\
\text { and compassion }\end{array}$ \\
\hline $\begin{array}{l}\text { Bahl et al., 2016, } \\
\text { J. Public Policy \& } \\
\text { Marketing }\end{array}$ & $\begin{array}{l}\text { Literature } \\
\text { review }\end{array}$ & $\begin{array}{l}\text { Attention, acceptance, } \\
\& \text { awareness }\end{array}$ & $\begin{array}{l}\text { Consumer, societal, and } \\
\text { environmental well-being }\end{array}$ & $\mathrm{N} / \mathrm{A}$ \\
\hline $\begin{array}{l}\text { Fischer et al., } 2017, \\
\text { J. Cleaner Production }\end{array}$ & $\begin{array}{l}\text { Literature } \\
\text { review }\end{array}$ & $\begin{array}{l}\text { Awareness of moment } \\
\text { to moment experience }\end{array}$ & N/A & N/A \\
\hline $\begin{array}{l}\text { Lim, 2017, } \\
\text { J. Business Research }\end{array}$ & $\begin{array}{l}\text { Literature } \\
\text { review }\end{array}$ & $\begin{array}{l}\text { Awareness and } \\
\text { attention }\end{array}$ & Responsible consumption & $\mathrm{N} / \mathrm{A}$ \\
\hline \multicolumn{5}{|l|}{ Empirical studies } \\
\hline $\begin{array}{l}\text { Brown and Kasser, 2005, } \\
\text { Social Indicators Research }\end{array}$ & Survey & MAAS & $\begin{array}{l}\text { Subjective well-being, } \\
\text { ecologically responsible } \\
\text { behavior }\end{array}$ & N/A \\
\hline $\begin{array}{l}\text { Amel et al., 2009, } \\
\text { Ecopsychology }\end{array}$ & Survey & $\begin{array}{l}\text { FFMQ (only } 2 \\
\text { subscales including } \\
\text { acting with awareness } \\
\text { \& observing) }\end{array}$ & $\begin{array}{l}\text { Single-item Green Scale (i.e., } \\
\text { frequency of choosing } \\
\text { sustainable option) }\end{array}$ & $\mathrm{N} / \mathrm{A}$ \\
\hline $\begin{array}{l}\text { Jacob et al., 2009, Social } \\
\text { Indicators Research }\end{array}$ & Mailed survey & $\begin{array}{l}\text { 4-item scale to } \\
\text { measure mindfulness } \\
\text { meditation practice }\end{array}$ & $\begin{array}{l}11 \text { items of ecologically } \\
\text { sustainable behavior, } \\
\text { including } 4 \text { items for } \\
\text { recycling, } 3 \text { items for } \\
\text { sustainable household } \\
\text { choices, and } 4 \text { items for } \\
\text { sustainable food practices }\end{array}$ & N/A \\
\hline
\end{tabular}




\begin{tabular}{|c|c|c|c|c|}
\hline $\begin{array}{l}\text { Ruedy and Schweitzer, } \\
\text { 2011, J. Business Ethics }\end{array}$ & $\begin{array}{l}\text { Questionnaire } \\
\text { survey and lab } \\
\text { experiment }\end{array}$ & MAAS & $\begin{array}{l}\text { Tendency to make ethical } \\
\text { decisions, measured with the } \\
\text { Self-reported Inappropriate } \\
\text { Negotiation } \\
\text { Strategies Scale (SINS) such } \\
\text { as cheating }\end{array}$ & $\mathrm{N} / \mathrm{A}$ \\
\hline $\begin{array}{l}\text { Williams and Grisham, } \\
\text { 2012, } \\
\text { Cognitive Therapy Research }\end{array}$ & Surveys & MAAS & $\begin{array}{l}\text { Impulsivity and Compulsive } \\
\text { buying }\end{array}$ & N/A \\
\hline $\begin{array}{l}\text { Barbaro and Pickett, } 2016, \\
\text { Personality and Individual } \\
\text { Differences }\end{array}$ & Surveys & $\begin{array}{l}\text { FFMQ (composite } \\
\text { score of the five } \\
\text { facets) }\end{array}$ & $\begin{array}{l}17 \text { daily pro-environmental } \\
\text { behaviors }\end{array}$ & $\begin{array}{l}\text { Connectedness to } \\
\text { nature }\end{array}$ \\
\hline $\begin{array}{l}\text { Park and Dhandra, 2017, } \\
\text { Personality and Individual } \\
\text { Differences }\end{array}$ & Survey & $\begin{array}{l}\text { CAMS-R (Awareness, } \\
\text { attention, present- } \\
\text { focus, non-judgement) }\end{array}$ & Impulsive buying tendency & $\begin{array}{l}\text { Four dimensions } \\
\text { of emotional } \\
\text { intelligence }\end{array}$ \\
\hline $\begin{array}{l}\text { Böhme et al., 2018, } \\
\text { Sustainability }\end{array}$ & $\begin{array}{l}\text { Interview, } \\
\text { Experiment }\end{array}$ & $\begin{array}{l}\text { 8-week mindfulness- } \\
\text { based interventions, } \\
\text { CHIME-A scale (only } \\
\text { use the three subscales } \\
\text { related to mindful } \\
\text { awareness) }\end{array}$ & $\begin{array}{l}\text { Sustainable consumption } \\
\text { behavior in food and clothing, } \\
\text { sustainable consumption } \\
\text { attitudes, material values, } \\
\text { compensatory consumption }\end{array}$ & N/A \\
\hline $\begin{array}{l}\text { Geiger et al., 2018, } \\
\text { Frontiers in Psychology }\end{array}$ & Online surveys & $\begin{array}{l}\text { KIMS, Awareness } \\
\text { CHIME }\end{array}$ & $\begin{array}{l}44 \text { Ecological Behaviors } \\
\text { (GEB scale) }\end{array}$ & Health behavior \\
\hline $\begin{array}{l}\text { Panno et al., 2018, } \\
\text { Environment and Behavior }\end{array}$ & Surveys & MAAS & Pro-environmental behavior & $\begin{array}{l}\text { Social dominance } \\
\text { orientation }\end{array}$ \\
\hline $\begin{array}{l}\text { Dhandra, 2019, } \\
\text { Ecological Economics }\end{array}$ & Survey & MAAS & $\begin{array}{l}\text { Life satisfaction, green } \\
\text { purchase intention, } \\
\text { social conscious purchasing, } \\
\text { frugal purchasing, } \\
\text { materialism }\end{array}$ & $\mathrm{N} / \mathrm{A}$ \\
\hline
\end{tabular}

* In chronological order. 


\section{References in Appendix only}

Böhme, T., Stanszus, L., Geiger, S., Fischer, D. and Schrader, U. (2018), "Mindfulness Training at School: A Way to Engage Adolescents with Sustainable Consumption?", Sustainability, Vol. 10 No. 10. DOI: 10.3390/su10103557.

Dhandra, T.K. (2019), "Achieving triple dividend through mindfulness: More sustainable consumption, less unsustainable consumption and more life satisfaction", Ecological Economics, Vol. 161, pp. 83-90.

International Personality Item Pool (2019), https://ipip.ori.org/, accessed 12 August 2019. Jacob, J., Jovic, E. and Brinkerhoff, M.B. (2009), "Personal and planetary well-being: Mindfulness meditation, pro-environmental behavior and personal quality of life in a survey from the social justice and ecological sustainability movement", Social Indicators Research, Vol. 93 No. 2, pp. 275-294.

Park, H.J. and Dhandra, T.K. (2017), "Relation between dispositional mindfulness and impulsive buying tendency: Role of trait emotional intelligence", Personality and Individual Differences, Vol. 105, pp. 208-212.

Ruedy, N.E. and Schweitzer, M.E. (2010), "In the moment: The effect of mindfulness on ethical decision making”, Journal of Business Ethics, Vol. 95 No. S1, pp. 73-87.

Williams, A.D. and Grisham, J.R. (2012), "Impulsivity, emotion regulation, and mindful attentional focus in compulsive buying", Cognitive Therapy and Research, Vol. 36 No. 5, pp. 451-457. 